\title{
Increasing Nitrogen Concentration in Hydroponic Solutions Affects Onion Flavor and Bulb Quality
}

\author{
W.M. Randle \\ Department of Horticulture, University of Georgia, Athens, GA 30602-7273
}

\begin{abstract}
AdDitional Index words. Allium cepa, nitrate, ammonium, pyruvic acid, 1-propenyl cysteine sulfoxide, methyl cysteine sulfoxide, S-propyl cysteine sulfoxide
\end{abstract}

\begin{abstract}
To test the effects of high nitrogen (N) fertilization levels on onion quality and bulb flavor, 'Granex 33' onions (Allium cepa $\mathrm{L}$.) were greenhouse grown in hydroponic solution culture with increasing $\mathbf{N}$ concentrations. Nitrogen was adjusted in the solutions with $\mathrm{NH}_{4} \mathrm{NO}_{3}$ and increased incrementally from $0.22 \mathrm{~g} \cdot \mathrm{L}^{-1}$ to $0.97 \mathrm{~g} \cdot \mathrm{L}^{-1}$ over five treatments. Plants were harvested at maturity and subjected to quality, flavor, and mineral analysis. As solution $\mathrm{N}$ increased, bulb fresh weight and bulb firmness decreased linearly. Gross flavor intensity, as measured by enzymatically developed pyruvic acid (EPY) increased linearly for $N$ concentrations between 0.22 and $0.78 \mathrm{~g} \cdot \mathrm{L}^{-1}$, but EPY was reduced slightly in bulbs grown at the highest $\mathrm{N}$ level $\left(0.97 \mathrm{~g} \cdot \mathrm{L}^{-1}\right)$. Soluble solids content was unaffected by solution $\mathrm{N}$ concentration. Solution $\mathbf{N}$ had an affect on flavor quality. Methyl cysteine sulfoxide, which gives rise to cabbage (Brassica $\mathrm{L}$. sp. $)$ and fresh onion flavors upon eating, generally increased in concentration as solution $\mathrm{N}$ increased. 1-Propenyl cysteine sulfoxide, which imparts heat, mouth burn, pungency, and raw onion flavors increased between the two lowest $\mathrm{N}$ concentrations, and then decreased as solution $\mathrm{N}$ increased. Propyl cysteine sulfoxide, which imparts fresh onion and sulfur flavors upon eating, generally increased with increasing solution $\mathrm{N}$ concentration. Several minerals were also affected by solution $\mathrm{N}$ concentration. Total bulb $\mathrm{N}$ and $\mathrm{NO}_{3}{ }^{-}$increased linearly while $\mathrm{B}$, Ca, and $\mathrm{Mg}$ decreased linearly. Total bulb $\mathrm{S}$ and $\mathrm{K}$ increased and then decreased quadratically in response to increasing solution $N$. Nitrogen fertility can have a pronounced affect on onion flavor and as a consequence, needs to be considered when growing onions for specific flavor quality and nutritional attributes.
\end{abstract}

Onion (Allium cepa) growth, maturity, and yield respond to nitrogen (N) applications (Corgan and Kedar, 1990). While continuous $\mathrm{N}$ availability results in the highest yields, the goal for quality onion production is to gradually deplete $\mathrm{N}$ from the soil during the last stages of bulb development (Brewster, 1990). High $\mathrm{N}$ application in the later stages of bulb development delays maturation and produces soft bulbs which negatively affect handling and postharvest shelf life (Riekels, 1977).

Nitrogen fertility has influenced flavor characteristics in several vegetable crops. Dimethyl sulfide, which imparts the characteristic aroma of cooked sweet corn (Zea mays L. var. rugosa Bonaf.), increased in response to increased $\mathrm{N}$ fertilization for several hybrids that were tested (Wong et al., 1995). Capsaicin and dihydrocapsaicin, two compounds responsible for pungency in pepper (Capsicum annuиm L.) fruit, were influenced by $\mathrm{N}$ fertility treatments (Johnson and Decoteau, 1996).

The environment in which the plants grow can likewise affect onion flavor intensity and quality. Factors shown to affect onion flavor intensity and quality resulting from the enzymatic decomposition of S-alk(en)yl cysteine sulfoxide (ACSO) precursors include $\mathrm{SO}_{4}^{-}$availability, growing temperatures, and level of irrigation (Freeman and Mossadeghi, 1973; Platenius and Knott, 1941; Randle, 1997). While the effect of N on onion flavor has not been investigated, empirical evidence from commercial sweet onion production suggested that the level of $\mathrm{N}$ applied to the crop may have an effect on ultimate flavor development. Because it is not uncommon for onions to receive $\mathrm{N}$ levels above recommended rates, the objective of this research was to determine the influence of high $\mathrm{N}$ concentrations on onion flavor intensity and flavor quality.

Received for publication 13 May 1999. Accepted for publication 9 Nov. 1999. The cost of publishing this paper was defrayed in part by the payment of page charges. Under postal regulations, this paper therefore must be hereby marked advertisement solely to indicate this fact.

\section{Material and Methods}

Plant culture. On 8 Sept. 1996, 'Granex 33’ (Asgrow Seeds, Kalamazoo, Mich.) was seeded into sheets of Grodan cubes (Dk2640, Hedehusene, Denmark) and watered as needed. Seedlings in each sheet were fertilized weekly with $0.75 \mathrm{~L}$ of Peter's $20 \mathrm{~N}-$ 8.8P-16.6K water soluble fertilizer (Grace-Sierra Co., Milpitas, Calif.) at a rate of $200 \mathrm{mg} \cdot \mathrm{L}^{-1}$. The seedlings were greenhouse grown at days/nights of $25 / 20^{\circ} \mathrm{C}$ for 6 weeks under natural photoperiods and irradiance $\left(\approx 34^{\circ} \mathrm{N}\right.$ latitude). A broad spectrum fungicide [Bravo 720 (chlorothalonil), Fermenta Plant Protection Co., Mentor, Ohio] was applied as needed. Plants were transferred to 40-L plastic containers (Rubbermaid, Inc., Wooster, Ohio) on 18 Oct. 1996. Fifteen plants were placed in $2.2-\mathrm{cm}$ holes spaced at $10.6 \times 9.5 \mathrm{~cm}$ on each container lid. The containers were filled with $30 \mathrm{~L}$ of a half-strength modified Hoagland's solution prepared with deionized water (Hoagland and Arnon, 1950). Five $\mathrm{N}$ treatments were constructed by adjusting the amount of ammonium nitrate $\left(\mathrm{NH}_{4} \mathrm{NO}_{3}\right)$ in the solutions with other $\mathrm{N}$ sources (Table 1). The $\mathrm{N}$ concentration of treatment 3 was approximately that found in a half-strength Hoagland's solution. In addition, each solution contained $0.12 \mathrm{~g} \cdot \mathrm{L}^{-1} \mathrm{MgSO}_{4} \cdot 7 \mathrm{H}_{2} \mathrm{O}, 0.01 \mathrm{~g} \cdot \mathrm{L}^{-1}$ chelated iron, $1 \mathrm{mg} \cdot \mathrm{L}^{-1} \mathrm{H}_{3} \mathrm{BO}_{3}, 0.9 \mathrm{mg} \cdot \mathrm{L}^{-1} \mathrm{MnCl}_{2} \bullet 4 \mathrm{H}_{2} \mathrm{O}, 0.11$ $\mathrm{mg} \cdot \mathrm{L}^{-1} \mathrm{ZnSO}_{4} \cdot 7 \mathrm{H}_{2} \mathrm{O}, 0.04 \mathrm{mg} \cdot \mathrm{L}^{-1} \mathrm{CuSO}_{4} \cdot 5 \mathrm{H}_{2} \mathrm{O}$, and $0.01 \mathrm{mg} \cdot \mathrm{L}^{-1}$ $\mathrm{H}_{2} \mathrm{MoO}_{4} \cdot \mathrm{H}_{2} \mathrm{O}$. The experimental design was a randomized complete block using four replications and 15 plants per replication. Solutions were aerated with compressed air that was forced through airstones placed on the container bottom. Wire mesh was attached to each container lid to support the foliage at a $20-\mathrm{cm}$ height. Solutions were replaced biweekly to reestablish initial solution concentrations. The $\mathrm{pH}$ of the initial solutions was 5.2 which decreased to 5.1 after 2 weeks. Electrical conductivity (EC) of the initial and final solutions was monitored with a conductivity meter (model 09-326; Fisher Scientific, Pittsburgh, $\mathrm{Pa}$.). The EC of the initial solution was $\approx 1516 \mu \mathrm{S}$. Early in the 
experiment, EC decreased to $1381 \mu \mathrm{S}$ in a 2 -week period. By the end of the experiment, EC dropped to $878 \mu \mathrm{S}$ within the same period. Solutions were replenished to full volume every other day with deionized water.

The plants were grown to maturity at $25 / 20{ }^{\circ} \mathrm{C}$ day/ night temperatures under natural photoperiods and irradiance. The experiment was harvested 2 Mar. 1997 when $50 \%$ of the plants had soft pseudostems. At harvest, the roots were removed and the plants were dried at ambient greenhouse temperatures for $7 \mathrm{~d}$. The 10 most uniform bulbs in each replication were selected for analysis and weighed to the nearest gram.

All analyses were done on the combined tissues of each 10bulb replication. Five to 10 -mm-thick wedges were cut longitudinally from the bulbs. One wedge group was used to measure the ACSOs and precursor intermediates ( $\gamma \mathrm{GP})$, a second wedge group was used to determine enzymatically developed pyruvic acid (EPY) and soluble solids content (SSC). EPY and SSC measure gross flavor intensity and sugars, respectively. A third wedge group was used for mineral analysis. The remaining bulb tissue was subjected to a pressure test using a penetrometer (McCormick, Princeton, Ind.) to determine bulb firmness. The dry outer skins were removed and each bulb was punctured three times using a 5-mm-diameter probe. Data are reported in grams and are the mean of 30 punctures per treatment combination.

SOLUBLE SOLIDS CONTENT AND GROSS FLAVOR INTENSITY. Wedges from each 10-bulb group were juiced in a pneumatic press. Several drops of the juice were applied to a hand-held refractometer (Kernco, Tokyo, Japan) to measure soluble solids content (SSC). Gross flavor intensity for each treatment combination was also determined using the juice with the pyruvic acid method of Randle and Bussard (1993). EPY is used routinely to measure an onion's gross flavor intensity (Lancaster and Boland, 1990).

Flavor PRECURSORS AND INTERMediates. The ACSOs and $\gamma$ GPs, were extracted using a 12 methanol : 3 deionized-distilled (DD) water solution, and an $80 \%$ ethanol solution that was modified for bulb tissue from Lancaster and Kelly (1983). SMethyl glutathione [MeGTH; $0.5 \mathrm{mg} \cdot \mathrm{g}^{-1}$ fresh weight (FW)], gL-glutamyl-L glutamic acid $\left(\gamma \mathrm{gG} ; 0.2 \mathrm{mg} \cdot \mathrm{g}^{-1} \mathrm{FW}\right)$, and ( \pm )-S-1butyl-L-cysteine sulfoxide (BCSO; $1.0 \mathrm{mg} \cdot \mathrm{g}^{-1} \mathrm{FW}$ ) were used as internal standards and added to $18 \mathrm{~mL}$ of the solutions ( $1 \mathrm{~g} \mathrm{FW}$ equivalent). The solutions were dried using ambient air and redissolved in $1 \mathrm{~mL}$ DD water. A $0.5-\mathrm{mL}$ aliquot was then subjected to ion exchanged chromatography using a $10 \times 40-\mathrm{mm}$ column (Bio-Rad, Hercules, Calif.) with 3 mL Dowex $1 \times 8$ resin (200 to 400 mesh; Bio-Rad). Fractionation was carried out using acetic acid (HOAc) at four concentrations: 0.1, 0.2, 2, and $5 \mathrm{M}$. The fractions containing the ACSO and $\gamma \mathrm{GP}$ compounds $(0.1$ and $2 \mathrm{M})$ were each collected and dried using ambient air.

High performance liquid chromatography (HPLC) sample preparation and analysis were carried out according to Randle et al. (1995). Each dried sample fraction was resuspended in $1.0 \mathrm{~mL}$ DD water, a $100-\mu \mathrm{L}$ sample was transferred to a $1.5-\mathrm{mL}$ microcentrifuge vial, and dried in vacuo using a Labconco Centrivap Concentrator (Kansas City, Mo.). Upon dryness, $250 \mu \mathrm{L}$ of 1 ethanol : 1 triethylamine (TEA) : 1 DD water was added to each sample and dried again. Derivitization was performed by the addition of $100 \mu \mathrm{L}$ of freshly prepared 7 ethanol : 1 TEA : 1 phenylisothiocyanate (PITC) : 1 DD water to each sample. The vials were immediately flushed with $\mathrm{N}_{2}$, capped, and stored at room temperature for $20 \mathrm{~min}$. The derivitizing solution was then removed in vacuo. Samples were redissolved using $500 \mu \mathrm{L} 2$ acetonitrile (HPLC grade): 7 DD water and transferred to 1.5-mL glass vials before HPLC analysis.
A HPLC separator module (model 2690; Waters, Milford, Mass.) with a photodiode array detector (model 996; Waters) was used for analysis. A $250 \times 4.6-\mathrm{mm}, 5-\mu$ m column (Sphri-5 RP-18; Applied Biosystems, Foster City, Calif.) fitted with a $15 \times 3.2-$ mm, 7- $\mu \mathrm{m}$ guard column (RP-18 Newgard; Applied Biosystems) was used for separation. The column temperature was maintained at $30{ }^{\circ} \mathrm{C}$. Eluted compounds were detected at $254 \mathrm{~nm}$ and data were collected and recorded using a personal computer with Millenium chromatography manager software (version 2.15.01; Waters, Milford, Mass.). Peak assignment was carried out by comparing retention times with authentic standards (supplied by J.E. Lancaster, Crop and Food Research, Christchurch, New Zealand) as described by Randle et al. (1995).

Solvents were A) aqueous acetonitrile (60\%) and B) $0.14 \mathrm{M}$ sodium acetate with $0.05 \%$ TEA buffered to $\mathrm{pH} 6.5$ using glacial acetic acid. Solvents were filtered through a $0.45-\mathrm{mm}$ nylon filter (Magna; MSI, Westboro, Mass.). Forty-microliter sample volumes were injected onto the column. A flow rate of $1.0 \mathrm{~mL} \cdot \mathrm{min}^{-1}$ was used. The solvent gradient used was $15 \%$ A for $1.10 \mathrm{~min}$, $15 \%$ to $45 \%$ A over $21.1 \mathrm{~min}, 45 \%$ to $100 \%$ A over $1 \mathrm{~min}$, and a hold at $100 \%$ A for $14 \mathrm{~min}$. The flow was returned to the initial solvent gradient over $1 \mathrm{~min}$, and the column was reequilibrated for $12.9 \mathrm{~min}$ before the next sample was injected.

Mineral analysis. Bulb tissue was dried at $60^{\circ} \mathrm{C}$ in a forcedair oven (Model 630, National Appliance Co., Portland, Ore.) for $72 \mathrm{~h}$. The dried tissue was ground through a $0.5-\mathrm{mm}$ screen (Cyclotec, Model 1093, Tector, Hoganas, Sweden). Total S and N were determined using a Leco C-N-S machine (model 2000, St. Joseph, Mich.).

Sulfate and $\mathrm{NO}_{3}{ }^{-}$ion concentrations were quantified using anion chromatography. One-half gram ground tissue was extracted in $100 \mathrm{~mL}$ HPLC grade water for $30 \mathrm{~min}$ with agitation. Ten milliliters of the solution was then centrifuged at $7000 \mathrm{~g}_{\mathrm{n}}$ for 10 min (Sorvall, Norwalk, Conn.). The supernatant was filtered through a $0.22 \mathrm{~mm}$ filter unit (Millex-GV; Millipore, Molsheim, France) and $40 \mathrm{~mL}$ were injected onto an IC-Pak Anion HR column equipped with a anion guard pak (IC-Pak; Waters, Milford, Mass.). Column temperature was maintained at $30^{\circ} \mathrm{C}$. A Waters 2690 HPLC separator module with a 432 conductivity detector was used for analysis. A flow rate of $1.0 \mathrm{~mL} \cdot \mathrm{min}^{-1}$ was used with an isocratic sodium borate-gluconate solvent. Data were collected and recorded using a personal computer with Millenium chromatography manager software as described earlier. Quantification was performed using $10 \mathrm{mg} \cdot \mathrm{L}^{-1}$ concentrations of the sulfate and nitrate sodium salts (J.T. Baker, Phillipsburg, N.J.) as external standards. To determine the effect of increasing $\mathrm{NH}_{4} \mathrm{NO}_{3}$ on the nutrient balance of the bulb, $1 \mathrm{~g}$ dry weight (DW) of tissue was dry ashed and $\mathrm{B}, \mathrm{Ca}, \mathrm{Cu}, \mathrm{Fe}, \mathrm{K}, \mathrm{Mg}, \mathrm{Mn}, \mathrm{Mo}, \mathrm{Na}$, $\mathrm{P}$, and $\mathrm{Zn}$ were quantified using inductively coupled argon plasma spectrophotometry (Jarrell-Ash, Franklin, Mass.)

Statistical ANALYSIS. Data were subjected to analysis of variance and linear and polynomial regression procedures using StatMost software (DataMost, Salt Lake City, Utah). Percentage data was arcsine transformed prior to analysis.

\section{Results and Discussion}

BULB WEIGHT AND FIRMNESS. Increasing solution $\mathrm{N}$ affected bulb FW $(P=0.05, \mathrm{~F}=2.03)$ and bulb firmness $(P=0.01, \mathrm{~F}=5.3)$ (Table 2). Bulb weight decreased linearly $\left(\mathrm{y}=224.8-52.5 \mathrm{~N}, R^{2}\right.$ $=0.89$ ) from $216 \mathrm{~g}$ per bulb to $179 \mathrm{~g}$ per bulb as solution $\mathrm{N}$ increased. While continuous $\mathrm{N}$ fertility has resulted in highest 
Table 1. Different nutrient salts used to vary $\mathrm{N}$ in five hydroponic solutions and their total $\mathrm{NO}_{3}{ }^{-}$and $\mathrm{NH}_{4}{ }^{+}$equivalent to evaluate the effect of increasing $\mathrm{N}$ on 'Granex 33' onion flavor and bulb quality.

\begin{tabular}{|c|c|c|c|c|c|}
\hline $\mathrm{N}$ treatment & $\left(\mathrm{CaNO}_{3}\right) \cdot 4 \mathrm{H}_{2} \mathrm{O}$ & $\mathrm{KNO}_{3}$ & $\begin{array}{c}\mathrm{NH}_{4} \mathrm{NO}_{3} \\
\mathrm{~g} \cdot \mathrm{L}^{-1}\end{array}$ & $\mathrm{NH}_{4} \mathrm{H}_{2} \mathrm{PO}_{4}$ & $\begin{array}{l}\text { Total } \mathrm{NO}_{3}^{-} \\
\text {and } \mathrm{NH}_{4}^{+}\end{array}$ \\
\hline 1 & 0.825 & 0.124 & 0.000 & $\begin{array}{l}4.2 \\
0.018\end{array}$ & 0.22 \\
\hline 2 & 0.825 & 0.124 & 0.186 & 0.018 & 0.41 \\
\hline 3 & 0.825 & 0.124 & 0.373 & 0.018 & 0.60 \\
\hline 4 & 0.825 & 0.124 & 0.560 & 0.018 & 0.78 \\
\hline 5 & 0.825 & 0.124 & 0.746 & 0.018 & 0.97 \\
\hline
\end{tabular}

bulb yields, excess $\mathrm{N}$ will stimulate foliar growth and depress the growth of bulbs (Brewster, 1990). Bulb firmness decreased linearly $\left(\mathrm{y}=580-117 \mathrm{~N}, R^{2}=0.81\right)$ from $549 \mathrm{~g}$ to $451 \mathrm{~g}$ as solution $\mathrm{N}$ increased. High $\mathrm{N}$ applied late in the growth cycle has been shown to produce soft bulbs and decrease post harvest shelf life (Riekels, 1977).

SOLUBLE SOLIDS CONTENT AND GROSS FLAVOR INTENSITY. Bulb SSC was statistically unaffected by increasing solution $\mathrm{N}(P=$ 0.95). Mean SSC was 7.8\%, which is typical for 'Granex 33', and ranged from $7.75 \%$ to $7.95 \%$ among the $\mathrm{N}$-treatments. Gross flavor intensity, as measured by EPY responded significantly to the $\mathrm{N}$ solution treatments $(P=0.09, \mathrm{~F}=2.57)$. The response of EPY to increasing $\mathrm{N}$ was cubic $\left(\mathrm{y}=7.9-13.9 \mathrm{~N}+36.5 \mathrm{~N}^{2}-\right.$ $23.8 \mathrm{~N}^{3}, R^{2}=0.99$ ) (Table 2). Flavor intensity increased from 6.4 $\mu \mathrm{mol} \cdot \mathrm{g}^{-1} \mathrm{FW}$ at the lowest $\mathrm{N}$ treatment to $7.92 \mu \mathrm{mol} \cdot \mathrm{g}^{-1} \mathrm{FW}$ at the $\mathrm{N}$ treatment of $0.78 \mathrm{~g} \cdot \mathrm{L}^{-1}$ and then decreased to $7.02 \mu \mathrm{mol} \cdot \mathrm{g}^{-1} \mathrm{FW}$ at the highest $\mathrm{N}$ treatment. Pyruvic acid is a common decomposition product from all the flavor precursors, and is a broad indicator of gross flavor intensity in onions (Randle et al., 1998). These EPY concentrations were within the range of those previously reported for 'Granex 33' grown with similar $\mathrm{SO}_{4}^{-2}$ levels (Kopsell and Randle, 1997).

FLAVOR PRECURSORS AND INTERMEDIATES. Total and individual flavor precursors were assessed, as well as two biosynthetic intermediates in the precursor pathway, to better understand the effect of $\mathrm{N}$ on onion flavor quality. Decomposition of the individual precursors gives rise to different sensory attributes including the lachrymatory (tear producing) factor and the thiosulfinates which are responsible for the individual flavors of fresh cut onions (Block, 1992). Changes in the concentration or ratio of individual flavor precursors give rise to differences in onion flavor quality (Randle et al., 1994).

Total flavor precursor concentration responded significantly to the $\mathrm{N}$ concentration treatments $(P=0.04, \mathrm{~F}=3.53)$. The response of total ACSO to increasing $\mathrm{N}$ was cubic $(\mathrm{y}=-3.8+$ $\left.36.8 \mathrm{~N}-58 \mathrm{~N}^{2}+28.8 \mathrm{~N}^{3}, R^{2}=0.99\right)($ Table 3 ). Total ACSO concentration increased from the lowest $\mathrm{N}$ concentration (1.9 $\left.\mathrm{mg} \cdot \mathrm{g}^{-1} \mathrm{FW}\right)$ to the midlevel treatment $\left(3.67 \mathrm{mg} \cdot \mathrm{g}^{-1} \mathrm{FW}\right)$, de- creased (3.31 mg. $\left.\mathrm{g}^{-1} \mathrm{FW}\right)$, and then increased at the highest $\mathrm{N}$ concentration $\left(3.65 \mathrm{mg} \cdot \mathrm{g}^{-1} \mathrm{FW}\right)$. One should expect similar responses of EPY and ACSO because EPY is produced, theoretically, in equal molar concentrations with total ACSO decomposition (Schwimmer and Weston, 1961). However, while the response for EPY and total ACSO were both cubic, the changes in slope of the regression equations were different between the two. A poor association between total ACSO concentration and EPY has been reported earlier (Randle et al., 1995) and may be attributed to differential decomposition of the individual ACSOs in onion macerates (Lancaster et al., 1998). Methyl cysteine sulfoxide (MCSO) and propyl cysteine sulfoxide (PCSO) were incompletely decomposed in onion macerates while 1-PRENCSO was instantaneously and fully decomposed (Lancaster et al., 1998). Changes in the ratios of the individual ACSOs in response to increasing $\mathrm{N}$ concentration could, therefore, provide a possible explanation for discrepancies between EPY and ACSO responses. In addition, changes in individual ACSO concentrations and ratios would lead to changes in flavor quality. Within onions, 1PRENCSO was originally thought to be in highest concentration, while MCSO and PCSO were found in lower concentrations (Lancaster and Boland, 1990). There is increasing evidence, however, that the individual ACSO composition and concentration changes in response to different environmental effects (Kopsell and Randle, 1999; Randle et al., 1995).

Methyl cysteine sulfoxide was found in highest concentration among the individual ACSOs measured, and responded significantly to the $\mathrm{N}$ concentration treatments $(P=0.03, \mathrm{~F}=3.82)$. The trend of MCSO to increasing $\mathrm{N}$ was cubic $(\mathrm{y}=-3.6+30.3 \mathrm{~N}-$ $\left.47.1 \mathrm{~N}^{2}+23 \mathrm{~N}^{3}, R^{2}=0.99\right)$ (Table 3 ). Methyl cysteine sulfoxide concentration was $1.06 \mathrm{mg} \cdot \mathrm{g}^{-1} \mathrm{FW}$ at the low $\mathrm{N}$ level, increased to $2.63 \mathrm{mg} \cdot \mathrm{g}^{-1} \mathrm{FW}$ at the $0.60 \mathrm{~g} \cdot \mathrm{L}^{-1} \mathrm{~N}$ concentration, decreased and then increased to $2.72 \mathrm{mg} \cdot \mathrm{g}^{-1} \mathrm{FW}$ at the highest $\mathrm{N}$ concentration. Thiosulfinates with a methyl fragment from the decomposition of MCSO impart cabbage and fresh onion flavors upon eating (Randle et al., 1994). High MCSO concentration relative to the other ACSOs has been shown previously. Methyl cysteine sulfoxide was the dominant precursor when plants were grown at

Table 2. Effects of increasing solution $\mathrm{N}$ on mean bulb fresh weight (FW), bulb firmness, gross flavor intensity (as measured by pyruvic acid, EPY) and soluble solids content (SSC) and their standard errors in 'Granex 33' onions.

\begin{tabular}{|c|c|c|c|c|}
\hline $\begin{array}{l}\text { Solution N } \\
\left(\mathrm{g} \cdot \mathrm{L}^{-1}\right)\end{array}$ & $\begin{array}{c}\text { Bulb FW } \\
\text { (g) }\end{array}$ & $\begin{array}{l}\text { Firmness } \\
(\mathrm{g})\end{array}$ & $\begin{array}{c}\text { EPY } \\
(\mu \mathrm{mol} \cdot \mathrm{g} \mathrm{FW})\end{array}$ & $\begin{array}{l}\text { SSC } \\
(\%)\end{array}$ \\
\hline 0.22 & $216 \pm 11$ & $549 \pm 13$ & $6.4 \pm 0.2$ & 7.8 \\
\hline 0.41 & $200 \pm 16$ & $528 \pm 16$ & $6.7 \pm 0.7$ & 7.8 \\
\hline 0.60 & $196 \pm 10$ & $535 \pm 14$ & $7.6 \pm 0.3$ & 7.8 \\
\hline 0.78 & $176 \pm 13$ & $504 \pm 5$ & $7.9 \pm 0.2$ & 7.9 \\
\hline 0.97 & $179 \pm 9$ & $451 \pm 16$ & $7.0 \pm 0.1$ & 7.9 \\
\hline Regression $^{z}$ & L & L & C & NS \\
\hline
\end{tabular}

${ }^{\mathrm{Z}}$ Linear (L), cubic (C), or nonsignificant (NS) regression equations, respectively $(P=0.05)$. 
Table 3. Effects of increasing solution $\mathrm{N}$ on the means \pm SE for total flavor precursor concentration (ACSO), methyl cysteine sulfoxide (MCSO), 1-propenyl cysteine sulfoxide (1-PRENCSO), propyl cysteine sulfoxide (PCSO), and the biosynthetic intermediates 2-carboxypropylglutathione (2-Carb) and $\lambda$ glutamyl propenyl cysteine sulfoxide ( $\lambda$ GPCSO) in 'Granex 33' onions.

\begin{tabular}{|c|c|c|c|c|c|c|}
\hline $\begin{array}{l}\text { Solution N } \\
\left(\mathrm{g} \cdot \mathrm{L}^{-1}\right)\end{array}$ & ACSO & MCSO & 1-PRENCSO & PCSO & 2-Carb & $\lambda \mathrm{GPCSO}$ \\
\hline & \multicolumn{6}{|c|}{$\mathrm{mg} \cdot \mathrm{g}^{-1}$ fresh weight } \\
\hline 0.22 & $1.90 \pm 0.13$ & $1.06 \pm 0.08$ & $0.69 \pm 0.04$ & $0.15 \pm 0.02$ & $0.83 \pm 0.11$ & $1.51 \pm 0.05$ \\
\hline 0.41 & $3.55 \pm 0.31$ & $2.50 \pm 0.27$ & $0.76 \pm 0.02$ & $0.29 \pm 0.03$ & $0.61 \pm 0.04$ & $1.46 \pm 0.14$ \\
\hline 0.60 & $3.67 \pm 0.47$ & $2.63 \pm 0.43$ & $0.73 \pm 0.02$ & $0.31 \pm 0.06$ & $0.58 \pm 0.02$ & $1.36 \pm 0.07$ \\
\hline 0.78 & $3.31 \pm 0.25$ & $2.43 \pm 0.21$ & $0.66 \pm 0.04$ & $0.22 \pm 0.03$ & $0.51 \pm 0.12$ & $1.32 \pm 0.08$ \\
\hline 0.97 & $3.65 \pm 0.51$ & $2.72 \pm 0.45$ & $0.66 \pm 0.04$ & $0.28 \pm 0.05$ & $0.45 \pm 0.02$ & $1.26 \pm 0.09$ \\
\hline Regression $^{2}$ & $\mathrm{C}$ & $\mathrm{C}$ & $\mathrm{C}$ & $\mathrm{C}$ & $\mathrm{L}$ & $\mathrm{L}$ \\
\hline
\end{tabular}

${ }^{\mathrm{z}}$ Significant linear $(\mathrm{L})$ or cubic $(\mathrm{C})$ regression equations $(P=0.05)$.

very low solution $\mathrm{S}$ concentrations (Randle et al., 1995). However, as solution $\mathrm{S}$ concentrations increased to luxuriant levels, 1PRENCSO became the dominant precursor. In addition, when onions were grown in the presence of high sodium selenate concentrations, MCSO was found in highest concentration of the individual ACSOs measured (Kopsell and Randle, 1999).

1-Propenyl cysteine sulfoxide was intermediate in concentration among the individual ACSOs measured, and responded significantly to increasing solution $\mathrm{N}(P=0.10, \mathrm{~F}=2.24)$ (Table $3)$. The response of 1 -PRENCSO was cubic $(\mathrm{y}=0.35+2.33 \mathrm{~N}-$ $\left.4.1 \mathrm{~N}^{2}+2.1 \mathrm{~N}^{3}, R^{2}=0.99\right)$. 1-Propenyl cysteine sulfoxide accumulation was greatest at the second $\mathrm{N}$ treatment level and then decreased in concentration as solution $\mathrm{N}$ increased. Thiopropanal $\mathrm{S}$-oxide, the lacrymatoray factor, is only derived from 1PRENCSO. Thiosulfinates with a propenyl fragment from the decomposition of 1-PRENCSO impart heat, mouth burn, pungency, and raw onion flavors upon eating (Randle et al., 1994).

Propyl cysteine sulfoxide was detected in lowest concentration among the individual flavor precursors, and responded significantly to the $\mathrm{N}$ treatments $(P=0.09, \mathrm{~F}=2.51)$. A significant cubic trend $\left(\mathrm{y}=-0.47+4.1 \mathrm{~N}-6.9 \mathrm{~N}^{2}+3.5 \mathrm{~N}^{3}, R^{2}=0.97\right)$ for PCSO was found in response to increasing $\mathrm{N}$ (Table 3 ). Propyl cysteine sulfoxide increased from $0.15 \mathrm{mg} \cdot \mathrm{g}^{-1} \mathrm{FW}$ to $0.31 \mathrm{mg} \cdot \mathrm{g}^{-1} \mathrm{FW}$ from the lowest to the midlevel $\mathrm{N}$ concentration, decreased to 0.22 $\mathrm{mg} \cdot \mathrm{g}^{-1} \mathrm{FW}$, and then increased to $0.28 \mathrm{mg} \cdot \mathrm{g}^{-1} \mathrm{FW}$ at the highest $\mathrm{N}$ concentration. Thiosulfinates with a propyl fragment impart fresh onion and sulfur flavors upon eating (Randle et al., 1994).

The discrepancy between total ACSO concentration and EPY can be, in part, explained by the changes in ratio of MCSO to 1PRENCSO, if we take into account the incomplete decomposition of MCSO. It was proposed that pyruvic acid produced early in the decomposition of the flavor precursors subsequently inhibited the complete decomposition of all precursors (Lancaster et al., 1998). Pyruvic acid, or its precursor $\alpha$-iminopropionic acid, possibly competes with the cofactor, pyridoxal phosphate, for alliinase binding sites, thereby causing the inhibition. Because, alliinase is most efficient in catalyzing 1-PRENCSO (Schwimmer, 1969), and acts rapidly and completely in its decomposition, a large pool of pyruvic acid is formed early in onion macerates. Methyl cysteine sulfoxide decomposition, on the other hand, is slower, and it is proposed that the pool of pyruvic acid inhibits its complete decomposition. As the concentration of MCSO increases in relation to 1-PRENCSO, less EPY will be produced relative to the incomplete decomposition of MCSO. This can be seen in our data with increasing solution N. For example, when solution $\mathrm{N}$ increased from 0.6 to $0.97 \mathrm{mg} \cdot \mathrm{L}^{-1}$, total ACSO concentrations were similar (3.67 and $3.65 \mathrm{mg} \cdot \mathrm{g}^{-1} \mathrm{FW}$, respectively). However, the ratio of MCSO to 1-PRENCSO increased from 2.53 to 2.91, indicating increased concentrations of MCSO in relation to 1-PRENCSO. The change in ratio was accompanied by a decrease in EPY ( $7.63 \mathrm{mmol} \cdot \mathrm{g}^{-1} \mathrm{FW}$ to $\left.7.02 \mathrm{mmol} \cdot \mathrm{g} \mathrm{FW}\right)$ because MCSO decomposition was possibly reduced due to pyruvic acid inhibition of alliinase. Because PCSO was roughly one tenth the concentration of MCSO at each of the $\mathrm{N}$ treatment levels, PCSO did not appear to significantly influence the dynamics of enzymatic decomposition.

Several biosynthetic flavor intermediates were affected by solution $\mathrm{N}$ concentration. 2-Carboxypropyl glutathione (2-Carb) responded significantly to solution $\mathrm{N}$ concentrations $(P=0.001$, $\mathrm{F}=34.2)$. A significant linear decrease $\left(\mathrm{y}=0.87-0.45 \mathrm{~N}, R^{2}=\right.$ 0.87 ) was found with increasing $\mathrm{N}$ (Table 3). 2-Carboxypropyl glutathione is formed early in the biosynthetic pathway of 1PRENCSO and PCSO, but is not thought to be involved in the synthesis of MCSO (Block, 1992). With increasing solution N, one could expect a general decrease in 2-Carb as more $\mathrm{S}$ is metabolized through the MCSO pathway. $\gamma$ Glutamyl propenyl cysteine sulfoxide ( $\gamma$ GPCSO) is the penultimate peptide in the synthesis of 1-PRENCSO and responded significantly to solution

Table 4. Effects of increasing solution $\mathrm{N}$ on select bulb minerals and ion means in 'Granex 33' onions.

\begin{tabular}{lcccccccccccc}
\hline \hline $\begin{array}{l}\text { Solution } \mathrm{N} \\
\mathrm{g} \cdot \mathrm{L}^{-1}\end{array}$ & Total N & $\mathrm{NO}_{3}^{-}$ & Total S & $\mathrm{SO}_{4}^{-2}$ & $\mathrm{~B}$ & $\mathrm{Ca}$ & $\mathrm{Cu}$ & $\mathrm{Fe}$ & $\mathrm{K}$ & $\mathrm{Mg}$ & $\mathrm{P}$ & $\mathrm{Zn}$ \\
\hline & & & & & & & $\mathrm{mg} \cdot \mathrm{g}^{-1}$ dry weight & & & \\
0.22 & 131 & 0.33 & 42.9 & 4.1 & 0.016 & 2.38 & 0.024 & 0.065 & 16.3 & 1.01 & 4.26 & 0.018 \\
0.41 & 164 & 0.82 & 50.9 & 4.4 & 0.014 & 1.75 & 0.012 & 0.061 & 17.7 & 0.92 & 4.78 & 0.023 \\
0.60 & 179 & 0.84 & 52.6 & 4.2 & 0.013 & 1.55 & 0.009 & 0.066 & 16.7 & 0.88 & 4.83 & 0.025 \\
0.78 & 178 & 0.90 & 46.1 & 4.1 & 0.014 & 1.35 & 0.007 & 0.060 & 16.2 & 0.81 & 4.66 & 0.021 \\
0.97 & 193 & 0.87 & 46.6 & 4.0 & 0.011 & 1.08 & 0.011 & 0.063 & 15.7 & 0.81 & 5.14 & 0.024 \\
Regression & $\mathrm{L}$ & $\mathrm{L}$ & $\mathrm{C}$ & $\mathrm{NS}$ & $\mathrm{L}$ & $\mathrm{L}$ & $\mathrm{NS}$ & $\mathrm{NS}$ & $\mathrm{Q}$ & $\mathrm{L}$ & $\mathrm{NS}$ & $\mathrm{NS}$ \\
\hline
\end{tabular}

${ }^{\mathrm{z}}$ Significant linear $(\mathrm{L})$, quadratic $(\mathrm{Q})$, or cubic $(\mathrm{C})$ or nonsignificant (NS) regression equations $(P=0.05)$. 
N concentration $(P=0.11, \mathrm{~F}=2.1)$. A significant linear decrease (y $\left.=1.59-0.34 \mathrm{~N}, R^{2}=0.98\right)$ was found for $\gamma \mathrm{GPCSO}$ with increasing $\mathrm{N}$ (Table 3). The $\gamma$ GPCSO decrease follows the concomitant general decrease in 1-PRENCSO concentration and supports the apparent preference for $\mathrm{S}$ to be metabolized through the MCSO pathway at higher solution $\mathrm{N}$ concentrations.

Mineral Analysis. Onions are a reliable source of several essential mammalian minerals, so it is important to understand how they change in concentration in response to increasing solution $\mathrm{N}$. Total bulb $\mathrm{N}$ responded significantly to increasing solution $\mathrm{N}(P=0.04, \mathrm{~F}=3.2)$. A significant linear increase $\left(R^{2}=\right.$ $0.63 ; \mathrm{y}=1.25+0.73 \mathrm{~N})$ was found for total bulb $\mathrm{N}$ with increasing solution $\mathrm{N}$ (Table 4). Nitrate accumulation in the bulbs also responded significantly to increasing solution $\mathrm{N}(\mathrm{P}=0.03)$. Nitrate, however, was a minor component of total bulb N. Nitrate content ranged from $0.25 \%$ to $0.5 \%$ of total bulb $\mathrm{N}$, suggesting that onions store $\mathrm{N}$ in forms other than $\mathrm{NO}_{3}^{-}$.

Compared to many other plants, onions accumulate large amounts of $\mathrm{S}$ that is metabolized primarily through the flavor precursor biosynthetic pathway (Lancaster and Boland, 1990). Although solution $\mathrm{S}$ concentrations did not change with $\mathrm{N}$ treatments, total bulb $S$ responded significantly to increasing solution $\mathrm{N}(P=0.001, \mathrm{~F}=7.3)$. The response to increasing $\mathrm{N}$ was cubic $\left(R^{2}\right.$ $\left.=0.93, \mathrm{y}=0.09+2.2 \mathrm{~N}-3.5 \mathrm{~N}^{2}+1.7 \mathrm{~N}^{3}\right)$ and ranged from 42.9 $\mathrm{mg} \cdot \mathrm{g}^{-1}$ DW to $52.6 \mathrm{mg} \cdot \mathrm{g}^{-1} \mathrm{DW}$ (Table 4). Onions have been shown to accumulate as much as $100 \mathrm{mg} \cdot \mathrm{g}^{-1} \mathrm{DW}$ of total bulb $\mathrm{S}$ (Randle, 1992). Increasing $\mathrm{NH}_{4}{ }^{+}$as a percentage of total solution $\mathrm{N}$ increased total bulb $\mathrm{S}$ in a previous study (Gamiely et al., 1991). Bulb $\mathrm{SO}_{4}^{-2}$ responded significantly to increasing solution $\mathrm{N}(P=$ $0.008, \mathrm{~F}=4.69)$ although there were no significant regression responses. Sulfate content ranged from $8 \%$ to $9.5 \%$ of total bulb $\mathrm{S}$. In a previous study, onions were shown to accumulate significant levels of $\mathrm{SO}_{4}^{-2}$, especially at high $\mathrm{S}$ fertility levels where as much as $48 \%$ of the total bulb S was $\mathrm{SO}_{4}^{-2}$ (Randle et al., 1999). Although total bulb $\mathrm{S}$ correlated poorly with over all flavor intensity among a broad range of onion accessions (Randle, 1992), an onion's ability to partition $\mathrm{S}_{\text {as }} \mathrm{SO}_{4}^{-2}$ during its metabolism was important in over all flavor development as measured by EPY (Randle et al., 1999). Those onions that partition little $S$ as $\mathrm{SO}_{4}^{-2}$ were more pungent than those that accumulated larger amounts of $\mathrm{SO}_{4}{ }^{-2}$. In the current study, the lowest EPY (6.4 $\mu \mathrm{mol} \cdot \mathrm{g} \mathrm{FW}$ ) was associated with the largest percentage of $\mathrm{S}$ as $\mathrm{SO}_{4}^{-2}(9.5 \%)$, and supports the earlier report.

Boron $(P=0.01), \mathrm{Ca}(P=0.01), \mathrm{Mg}(P=0.01)$, and $\mathrm{K}(P=$ $0.05)$ were bulb tissue cations significantly affected by increasing solution $\mathrm{N}$ (Table 4). Boron decreased linearly $(\mathrm{y}=0.017-$ $0.009 \mathrm{~N}, R^{2}=0.77$ ) from 0.016 to $0.011 \mathrm{mg} \cdot \mathrm{g}^{-1} \mathrm{DW}$, Ca decreased linearly $\left(\mathrm{y}=2.58-1.60 \mathrm{~N}, R^{2}=0.79\right)$ from 2.38 to $1.08 \mathrm{mg} \cdot \mathrm{g}^{-1}$ $\mathrm{DW}$, and $\mathrm{Mg}$ decreased linearly $\left(\mathrm{y}=1.05-0.28 \mathrm{~N}, \mathrm{R}^{2}=0.74\right)$ from 1.01 to $0.81 \mathrm{mg} \cdot \mathrm{g}^{-1} \mathrm{DW}$. The $\mathrm{K}$ response to increasing solution $\mathrm{N}$ was quadratic $\left(\mathrm{y}=16.34+3.83 \mathrm{~N}-4.73 \mathrm{~N}^{2}, R^{2}=0.60\right)$. An increase in bulb K occurred between the lowest two $\mathrm{N}$ treatments, which was followed by a steady decrease in bulb $\mathrm{K}$ as solution $\mathrm{N}$ increased. Increasing levels of $\mathrm{NH}_{4}^{+}$have been shown to depress essential cations in plant tissues (Mills and Jones, 1996). Copper, $\mathrm{Fe}, \mathrm{P}$, and $\mathrm{Zn}$ were unaffected by increasing solution $\mathrm{N}$.

In this experiment, my objective was to evaluate the effects of excessive $\mathrm{N}$ fertility on onion flavor development and accumulation. Even though recommended $\mathrm{N}$ levels for onions are between 130 and $160 \mathrm{~kg} \cdot \mathrm{ha}^{-1}$ (Lorenz and Maynard, 1988), applications of between 300 and $500 \mathrm{~kg} \cdot \mathrm{ha}^{-1} \mathrm{~N}$ have occurred when growing mild onions on sandy loam soils (personal observations). While direct comparisons to field production can not be made, the lowest $\mathrm{N}$ treatment of $0.22 \mathrm{~g} \cdot \mathrm{L}^{-1}$, would approximate an $\mathrm{N}$ fertility rate of $\approx 300 \mathrm{~kg} \cdot \mathrm{ha}^{-1}$, assuming a population of 148,000 plants per ha. As $\mathrm{N}$ concentration increased in our study, plant growth was affected. Higher $\mathrm{N}$ decreased bulb weight and bulb firmness, which are characteristics in onion indicative of excessive $\mathrm{N}$ fertility (Riekels, 1977). High $\mathrm{N}$ will stimulate foliar growth at the expense of bulb size. Solution $\mathrm{N}$ concentrations affected overall flavor intensity of bulb onion, but not SSC. Interestingly, N concentration had a direct affect on the biosynthetic pathway leading to flavor precursor synthesis. Prior to this study, we suspected that increases in flavor intensity from excessive $\mathrm{N}$ would result from stimulated onion growth and foliar mass. Flavor precursors are synthesized primarily in onion leaves (Lancaster and Boland, 1990). As solution N concentration increased, MCSO synthesis was favored over 1-PRENCSO synthesis. Changes in precursor concentration and composition will have an affect on onion flavor intensity and quality, respectively. The biosynthetic intermediates leading to flavor precursor synthesis were also affected by $\mathrm{N}$ solution concentration, and supported the trends in their terminal products. The increased activity of the MCSO pathway with increasing $\mathrm{N}$ resulted in a corresponding decrease in 2-Carb and IGPCSO which are biosynthetic intermediates associated only with 1-PRENCSO and PCSO synthesis. Increasing $\mathrm{NH}_{4} \mathrm{NO}_{3}$ decreased the concentration of many bulb cations, including $\mathrm{Ca}$ and $\mathrm{Mg}$. Nitrogen fertilization, therefore, can have a pronounced influence on onion flavor quality, and as a consequence, needs to be considered when growing onions for specific flavor intensity and quality attributes.

\section{Literature Cited}

Block, E. 1992. The organosulfur chemistry of the genius AlliumImplications for the organic chemistry of sulfur. Angew. Chem. Intl. Educ. Eng. 31:1135-1178.

Brewster, J.L. 1990. Cultural systems and agronomic practices in temperate climates, p. 1-30. In: H.D. Rabinowitch and J.L. Brewster (eds.). Onions and allied crops. vol. 2. CRC Press, Boca Raton, Fla.

Corgan, J.N. and N. Kedar. 1990. Onion cultivation in subtropical climates, p. 31-47. In: H.D. Rabinowitch and J.L. Brewster (eds.). Onions and allied crops. vol. 2. CRC Press, Boca Raton, Fla.

Freeman, G.G. and N. Mossadeghi. 1973. Studies on the relationship between water regime and flavour strength in water cress [Rorippa nasturium-aquaticum (L.) Hayek], cabbage (Brassica oleracea var. capitata) and onion (Allium cepa L.). J. Hort. Sci. 48:365-378.

Gamiely, S., W.M. Randle, H.A. Mills, and D.A. Smittle. 1991. Onion plant growth, bulb quality, and water uptake following ammonium and nitrate nutrition. HortScience 26:1061-1063.

Hoagland, D.R. and D.I. Arnon. 1950. The water culture method for growing plants without soil. Calif. Agr. Expt. Sta. Circ. 347.

Johnson, C.D. and D.R. Decoteau. 1996. Nitrogen and potassium fertility affects jalapeno pepper plant growth, pod yield, and pungency. HortScience 31:1119-1123.

Kopsell, D.E. and W.M. Randle. 1997. Onion cultivars differ in pungency and bulb quality changes during storage. HortScience 32:12601263.

Kopsell, D.A. and W.M. Randle. 1999. Selenium affect the S-alk(en)yl cysteine sulfoxides among short-day onion cultivars. J. Amer. Soc. Hort. Sci. 124:307-311.

Lancaster, J.E. and M.J. Boland. 1990. Flavor biochemistry, p. 33-72. In: H.D. Rabinowitch and J.L. Brewster (eds.). Onions and allied crops. vol. 3. CRC Press, Boca Raton, Fla.

Lancaster, J.E. and K.E. Kelly. 1983. Quantitative analysis of the Salk(en)yl-L-cysteine sulphoxides in onion (Allium cepa L.). J. Sci. Food Agr. 34:1229-1235.

Lancaster, J.E., M.L. Shaw, and W.M. Randle. 1998. Differential hy- 
drolysis of alk(en)yl cysteine sulphoxides by alliinase in onion macerates: Flavour implications. J. Sci. Food Agr. 78:367-372.

Lorenz, O.A. and D.N. Maynard. 1988. Knott's handbook for vegetable growers. 3rd ed.. Wiley-Interscience Publication, New York.

Mills, H.A. and J.B. Jones, Jr. 1996. Plant analysis handbook II: A practical sampling, preparation, analysis, and interpretation guide. MicroMacro Publishing, Athens, Ga.

Platenius, H. and J.E. Knott. 1941. Factors affecting onion pungency. J. Agr. Res. 62:371-379.

Randle, W.M. 1992. Onion germplasm interacts with sulfur fertility for plant sulfur utilization and bulb pungency. Euphytica 59:151-156.

Randle, W.M. 1997. Onion flavor chemistry and factors influencing flavor intensity, p. 41-52. In: S.J. Risch and C. Ho (eds.). Spices: Flavor chemistry and antioxidant properties. Amer. Chem. Soc. Symp. Ser. 660, Wash., D.C.

Randle, W.M., E. Block, M.H. Littlejohn, D. Putman, and M.L. Bussard. 1994. Onion (Allium cepa) thiosulfinates respond to increasing sulfur fertility. J. Agr. Food Chem. 42:2085-2088.

Randle, W.M. and M.L. Bussard. 1993. Streamlining onion pungency analyses. HortScience 28:60.

Randle, W.M., D.A. Kopsell, D.E. Kopsell, R.L. Snyder, and R. Tor- rance. 1998. Field sampling short-day onions for bulb pungency. HortTechnology 8:329-332.

Randle, W.M., D.E. Kopsell, D.A. Kopsell, and R.L. Snyder. 1999. Total sulfur and sulfate accumulation in onion is affected by sulfur fertility. J. Plant Nutr. 22:45-51.

Randle, W.M., J.E. Lancaster, M.L. Shaw, K.H. Sutton, R.L. Hay, and M.L. Bussard. 1995. Quantifying onion flavor compounds responding to sulfur fertility-Sulfur increases levels of alk(en)yl cysteine sulfoxides and biosynthetic intermediates. J. Amer. Soc. Hort. Sci. 120:10751081.

Riekels, J.W. 1977. Nitrogen water relationships of onions grown on organic soils. J. Amer. Soc. Hort. Sci. 202:139-142.

Schwimmer, S. 1969. Characterization of S-propenyl-L-cysteine sulfoxide as the principle endogenous substrate of L-cysteine sulfoxide lyase of onion. Arch. Biochem. Biophys. 130:312-320.

Schwimmer, S. and W.J. Weston. 1961. Enzymatic development of pyruvic acid in onion as a measure of pungency. J. Agr. Food Chem. 9:301-304.

Wong, A.D., J.M. Swiader, and J.A. Juvik. 1995. Nitrogen and sulfur fertilization influences aromatic flavor components in shrunken 2 sweet corn kernels. J. Amer. Soc. Hort. Sci. 120:771-777. 